University of Pennsylvania ScholarlyCommons

1969

\title{
Kirman and the Middle East: Paul Ward English's City and Village in Iran: Settlement and Economy in the Kirman Basin
}

Brian Spooner

University of Pennsylvania, spooner@sas.upenn.edu

Philip C. Salzman

Follow this and additional works at: http://repository.upenn.edu/anthro_papers

Part of the Anthropology Commons

\section{Recommended Citation}

Spooner, B., \& Salzman, P. C. (1969). Kirman and the Middle East: Paul Ward English's City and Village in Iran: Settlement and

Economy in the Kirman Basin. Iran, 7 107-113. Retrieved from http://repository.upenn.edu/anthro_papers/134 


\title{
Kirman and the Middle East: Paul Ward English's City and Village in Iran: Settlement and Economy in the Kirman Basin
}

\author{
Disciplines \\ Anthropology | Social and Behavioral Sciences
}




\title{
KIRMAN AND THE MIDDLE EAST: PAUL WARD ENGLISH'S CITY AND VILLAGE IN IRAN: SETTLEMENT AND ECONOMY IN THE KIRMAN BASIN
}

\author{
By Brian Spooner and Philip C. Salzman \\ "Few of us realize that geography is the prince of disciplines, combining the fruits \\ of geology, meteorology, anthropology, sociology, economics, and dozens of other \\ specialities. The good geographer is a philosopher" (Coon, 1964: 10).
}

\section{INTRODUCTION}

It would not, I think, be an exaggeration to say that the appearance of City and Village in Iran by Paul Ward English marks the beginning of a new stage in the steady development of academic writing on Iran. The book is concerned not with a ruler, or a period, nor with a city or a tribe or a village, but with a region. This is a new method of research which has been much discussed in recent years and in a larger sense has been responsible for new departures in the university teaching of oriental studies. This book is the first full scale study according to this method to appear concerning Iran. Though it is still perhaps early (at the time of writing it is still not yet two years since the book's publication), the authors of this review article consider that it has not received sufficient attention. The book is by a geographer. The method implies use and co-ordination of the points of view of other disciplines (in so far as they may bear on the subject). The present writers are social anthropologists, one of us with a strong area bias. As will appear below there is much in this book which we would wish to question. We welcome English's study and the wealth of interesting and detailed material which it makes available, and we consider it a real contribution to the study of Iran, but we disagree with certain points of his application of the method and consequently of his interpretation of his material. The concept of regional studies grew out of a growing consciousness of disciplinary bias and isolation. It is possible that what follows will betray an anthropological bias. However, the pioneer aspect of English's work demands thorough public interdisciplinary discussion. It is in this spirit that the following critiques were written.

Brian SPOONER

I

I. "The villager of Iran, whether sharecropper, weaver, or herder, is inextricably involved in an urban-dominated, regional economic organization and probably was so in the past " (p. 88). ${ }^{1}$ Furthermore, the "concept of urban dominance ... explains some of the perplexities produced by village studies elsewhere in the Middle East" (p. xix). These conclusions are based upon Dr. English's analysis of settlement and economy in the Kirmān Basin.

English approaches his data with the heuristic proposition that cities, villages and herding camps are not pristine isolates, each solving the problems of survival on its own. Rather, these different settlement types are inextricably interdependent, and therefore the region, and not the single community, must be the unit of study (p. xviii). Such an approach, English suggests, will not only illuminate new dimensions of understanding, but will correct old confusions about social and economic organization in the Middle East which are the result of scholarly emphasis upon the internal structure of single communities (pp. xvii-xviii).

${ }^{1}$ References are to English 1966, unless otherwise indicated. 
Beginning with regional analysis as a heuristic device, English concludes with the substantive hypothesis of urban dominance in Iran and the Middle East. What are the intervening steps in the argument, and to what extent do the conclusions follow from the data presented?

2. To summarize English's data, there are two factors that result in urban dominance in the Kirmān Basin: capital for agriculture and industry, and co-ordination of industrial processes. Because of the scanty rainfall, the Basin depends upon an elaborate and extensive system of qanatts (underground irrigation tunnels). On such a scale, the qanäts are extremely expensive to build and maintain, and therefore necessitate large amounts of capital and complex regulations about ownership and use. The capital is supplied by wealthy city dwellers (of Kirmān City) who then control the water rights and usage and receive a return for water use by agriculturalists. In addition to the water rights, most of the land itself is owned by landowners, who often provide land, seed and draught animals as well as water. For providing labour, the sharecropper receives 30 per cent of the crops. However, the town and village dwellers of the Basin are by no means mainly agriculturalists. Only in the small highland villages do the inhabitants live by agriculture; the majority of the inhabitants of the larger villages, of the regional sub-centres, and of Kirmān City itself, are professional people, merchants, weavers and unskilled labourers. The weavers, who make up the largest plurality, are part of a highly organized industry which is directed from Kirmān City through agents of the merchants. Raw materials, a great deal of which comes from flocks which are under contract and which are urban owned, flow into Kirmān City and are then distributed along with contracts to the weavers in the villages, and the finished rugs are returned to the City. Through capital control, land and water rights, and the organization of industry, the economic life of Kirmān Basin is owned and controlled by city dwellers, and thus the region can be characterized as urban dominated.

This analysis of the Kirmān Basin undermines "the traditional description of Middle Eastern 'villages' as physically isolated, homogeneous, subsistence settlements occupied primarily by agriculturalists" (p. I I 2). In fact, Kirmān Basin villages (I) have internal socio-economic differentiation, (2) vary in size and socio-economic function, and (3) are tied closely to the regional subcentres and urban centres on which they are dependent.

English suggests that there is good reason to believe that " the patterns of the Kirmann Basin are representative" of the Middle East as a whole (p. I I I), and therefore that "village morphology, economic structure, and territorial organization are products of centralized urban control of rural resources" (p. xviii).

3. To what extent is the Kirmān Basin representative of Iran in general and the entire Middle East? How confident can we be in applying these findings to the area as a whole?

English does not document the " representativeness " of the Kirmān Basin beyond saying that " the physical environment presents many of the same problems to permanent settlers as other Middle Eastern areas ", that is, little rainfall, scanty vegetation, and poor soils (p. xix). And yet even in this, Kirmān seems to be an extreme in Iran. For example, in precipitation, Kirmān received a yearly average of $172.75 \mathrm{~mm}$. (based on data for I957-6I, p. Io), one of the lowest of all populated areas in Iran. Compare the I 957 precipitation for Mashhad (263 mm.), Qum (269 mm.), Tabriz (299 mm.), Bīrjand (33 I mm.), Tehran (37 I mm.), Zanjān (479 mm.), Arāk (516 mm.), Hamadān (522 mm.), Shîrāz (652 mm.), and the lush Caspian Coast region (up to $2380 \mathrm{~mm}$., cf. Meteorological Yearbook 1957). Of course, precipitation data does not tell a great deal, and we do know that one or another form of irrigation is used throughout most of the country. But it is clear that we cannot assume homogeneity throughout Iran, and thus the extent to which Kirmān is representative must be demonstrated rather than assumed. And even where there is irrigation, large amounts of capital and central organization might not be necessary. The complexity and scope of the irrigation is the telling factor here, for as we have learned from Gray's The Sonjo of Tanganyika, small scale irrigation which is essential for production can be organized on a local level with control and labour from the village agriculturalists.

Is the extensive organization of the rug industry of Kirmān typical of other regions of Iran, and what takes its place in areas of the Middle East which do not produce rugs? Are the Turkoman, Baluchi and Qashqai rugs produced in the same manner as the rugs of Kirmān? Two questions thus arise: Are 
there areas of Iran and the Middle East where agriculturalists are in the majority and where craftsmen and other workers make up a small portion? And where there is large scale non-agricultural production, is it always organized on a centralized contract basis? It is far from clear that well-documented answers to these questions would indicate that Kirmān is representative of Iran and the Middle East.

Another consideration is the political aspect of " urban control ". Land and water rights and central organization are political as well as economic. And a political factor very representative of Iran and the Middle East in general is not in evidence in the Kirmān data: that is, tribal pastoralists. The tribes throughout the Zagros mountains, which cover a large part of Iran, and in the north-east and south-east of Iran, have not until just recently been under any kind of " urban domination ". Very often the villages were owned by or were political clients of the tribes (Barth; Cooper), a situation which is not atypical of other areas of the Middle East (Musil; Doughty). The cities and the tribes were sometimes opponents vying for control of the villages, and occasionally for control of the cities themselves. And throughout, the tribes, with their economic produce of meat, milk products, skins, wool, and wool products including rugs, were equal trading partners, as well as independent political agents, and could hardly be included under the label "urban dominated". Whether or not there was any evidence of them in Kirmān, surely the tribes must be taken into account in any model of regional organization in the Middle East.

Among the studies that English criticizes for following the " tripartite view of the Middle East", and thus using the city, village or tribe as the unit of study, is Stirling's Turkish Village (p. xvii, note 4). Now although Stirling does indeed emphasize internal structure, he examines two villages of quite different sizes and characteristics and takes pains to indicate the incoming and outgoing of men ard material and to account for their effects on the internal structure. It does not seem fair to criticize a man for having written a different book than one might have liked, as long as he takes into account all that is necessary for an accurate picture of the subject as he chooses it. However, the importance of this example here is its relevance to the substantive question of urban domination. If the Turkish village is urban dominated, and this does not seem to be indicated from the data presented in the monograph, the forces are not those at work in Kirmān. There are no landlords; almost all of the land is peasantheld. There is no large scale irrigation and thus no urban capital necessary for water. Almost everyone is a farmer, and although the influence of the market is felt, there is no centralized contract system. And since almost everyone farms, there is no urban-controlled industry. Therefore, even if a regional study is made, it would be unlikely to uncover " urban control of rural resources". This is not to say that regional analysis would not be illuminating, but rather that we must separate English's pleas to examine regions as wholes from his substantive hypothesis about urban domination. Regional studies ought to be done; urban domination must be tested.

4. If we cannot accept urban domination in the Middle East as a substantive conclusion, we can accept it as a variable to be examined. Urban domination must be conceptualized as a dimension having degrees from high urban domination to low urban domination; and the other elements of social life that vary as urban domination varies must be discovered. As suggested above, the degree of local self-sufficiency in production and the political balance of power are likely to be associated, although not necessarily in a simple fashion, with the degree of urban dominance. In any case, it is likely that English's model of urban dominance will teach us as much in its inapplicability as in its applicability.

Philip G. Salzman

I. The following critique is empirical rather than theoretical. Though I have driven through the Kirmān Basin (see map, p. 6) many times, I have never stopped to study it firsthand. However, my field experience elsewhere on the Iranian plateau leads me to question the generalization implied in the title: City and Village in Iran: Settlement and Economy in the Kirmän Basin. English is concerned to correct previous assumptions about villages in the Middle East: I disagree with his appreciation of these assumptions. 
However, my criticism aims primarily at redressing the balance in his interpretation. The imbalance may have arisen from over-correction of the imperfections in the existing literature. His own field material is limited to the Kirmān Basin itself, where he worked for eleven months, in I96I-62 and the emphasis throughout his interpretation of this material is on purely economic factors. By drawing attention to situations in other parts of the Iranian plateau and pointing out the relevance of political and oecological factors both in the Kirmann Basin and elsewhere, I wish on the one hand to show the importance of English's work, and on the other to restrict his generalization.

I am mainly concerned, therefore, with his Introduction, and Chapters 5 and 7 and the conclusion; I consider that the most valuable chapter-apart from the often excellent factual detail in the appendices -is Chapter 3, closely followed by 4 and 6.

2. The theoretical fulcrum of this book is that " the region, not a single community, is the unit of study" ... "There are strong patterns of inter-relatedness between every village and the city, and weaker social and economic ties among villages" ... "The field area (the Kirmān Basin) provides an excellent laboratory for testing this regional approach" (pp. xviii-xix).

Of these three propositions the first two are admirable; the third is misleading. I have myself made a plea for a type of area study in Iran in an article published in 1965 , and feel strongly that this approach is sorely needed. But what is the unit of study? What is a region? English devotes some space (cf. Introduction) to justifying the "approach" (the importance of which is unlikely to be disputed today), but nowhere suggests how we should in general choose and define our regions. Surely this is an important question. Unfortunately, because of the general validity English claims for the urban domination he finds in the Kirmān Basin, he appears to assume that every region-every unit of studymust contain a city. This is of course absurd. And this is one obvious reason why his thesis of urban domination cannot have as general a validity as he appears to claim.

The simple reason why it is absurd is that a number of villages within one hundred miles of the city of Kirmān are not included by English in his regional study (the Kirmān Basin) and could not feasibly be included in one region with any other city: they must therefore either be studied separately from any city, or not at all! In so far as my acquaintance with the Kirmān Basin allows me to judge, it would indeed seem to be a very interesting region to treat in a regional study-but not because it contains a city. Its fitness depends on the fact that it contains a group of settlements of varying size which bear closer sociological relationships to each other than to other settlements or communities outside the region.

English's argument is almost purely from economics, and he actually says: "Perhaps this interdependence between city and village is most striking in the economic sphere ". Of course economic ties are important, but they are not always primary and they seldom provide the whole explanation to any situation. The primary factors in this situation are oecological: firstly, that the coincidence of cultivable soil and water for irrigation together with the given level of technology allows a population of this size and in this particular settlement pattern; secondly, that the topography endorses a distinct break between this and other neighbouring patterns. Given this oecological situation, other factors-in particular those of economics-result. This is not oecological determinism. The oecological situation does little to shape the sociological relationships. What it does, is to define sites and size of possible agricultural (or pastoral) activity according to any given level of technology. Similarly, the topography itself suggests routes of communication according to the level of technology available. In seeking to choose and define, therefore, suitable regions for "regional study" we should look for what might be called " oecological units". ${ }^{2}$ Obviously, there are oecological units which from the point of view of any of the social sciences will not be suitable for regional study-because of lack or surfeit of population. Nevertheless, oecological criteria together with a consideration of patterns of settlement and pastoral activity should allow the definition of a suitable region.

3. "Kirmān's physical environment (Chapter I) presents many of the same problems to permanent settlers as other Middle Eastern areas. It lies in a mountain-ringed basin, has little rainfall, scanty

2 More specifically: areas of settled and/or nomadic communities which, because of a combination of factors of topography, natural conditions and technology, enjoy a network of socio- logical relationships primarily with each other, and only secondarily with communities outside the area. 
vegetation, and poor soils. All crops must be irrigated and protected from blowing sand; grazing resources have deteriorated, and the fuel problem is acute" (p. xix).

All this is certainly true of the Kirmān Basin, but it is extreme rather than typical. The most striking feature of the Kirmān Basin is the vital importance of qanäts (cf. Appendix D) to absolutely all agricultural activity, the length of these qanats, and the amount of capital and day-to-day expenditure which must be continually devoted to them. In only two other regions-whether on the plateau, within Iran, or anywhere else-do qanatts occupy a comparable position of economic and oecological importance: the region which includes the city of Yazd, and the plain of Gunābād (both of which are situated on the plateau). Yazd does, it is true, bear a reasonably close resemblance to the picture English draws of Kirmān, but the Gunābād plain is very different (cf. Tābandeh, I954). Traditionally, the plain of Gunābād contains seventeen villages, but no city or major centre. ${ }^{3}$ There can therefore be no question of urban dominance. Another very obvious reason why the Kirmān Basin can in no way be regarded as typical, is that it contains no nomadic pastoralists. In Iran, in general, this makes it exceptional rather than typical. It may of course be argued that the presence even of a largish body of fully nomadic pastoralists need not upset English's interpretation of urban dominance, since we could expect them to depend on the facilities of the city to sell their products and buy grain. However, the long history of the relationship between nomadic and settled on the Iranian plateau, and elsewhere in the Islamic world is more complex than this. The crux of the whole situation in Kirmann is that there can be no agriculture without qanäts (this is not unusual on the Iranian plateau, but it cannot be said to be altogether typical), and the topography and sedimentary fill of the basin is such that the cost of these qanats both in terms of capital investment and maintenance is unusually high. Nevertheless, they do produce enough water to support a city which can in turn afford the financial effort required.

4. This is perhaps enough at this stage to show that there is in the Kirmān Basin much that is in no way typical of other regions. Allowing a high degree of urban dominance in the Kirmān Basin itself, there are other factors which English has omitted. The most important of these is the extent to which processes of centralization, and Westernization or modernization, may have influenced the traditional patterns. For there is now a large degree of government participation in several sectors of the economy, and this is bound to heighten the effect of any economic - or other-domination from the city.

Secondly, English himself admits that " the economic structure of settlements in Kirmān varies, but agriculturalists are a majority only in the smallest, most remote villages and hamlets. Most of the people are weavers, merchants, professionals, and unskilled laborers. The organisation of economic activity in all settlements is dominated by city dwellers" (my italics) ... but "one reservation should be noted here. All settlements treated in this study lie within forty miles of Kirmān City. It seems probable that isolated peasant villages would be more common at greater distances from a city"! (p. xix and note 18 ). The type of urban domination English is talking about is bound to be economic, and it would be surprising indeed if the villages within forty miles of a city the size of Kirmān $(60,000)$ were not economically dominated by it. It is surely only natural that the farther the village is from the city the more distant its sociological relationship will also be. A very large proportion of Persian villages are more than forty miles away from any city. According to the official census figures of 1956 the rural population of Iran was I3,00 I, I4 I distributed among 49,054 villages of a mean size of only $265^{\circ} \mathrm{O}$ inhabitants each (Census, vol. I, p. 21). English defines a small village (i.e. settlements where most of the population practise agriculture) as one with a population of between 100 and 1000 (p. 33).

Finally, although it is noted that "shrines and mosques and their environs are often focal points of social and economic power in their respective settlements" (p. 57), religion in general could be made more use of in an assessment of " settlement and economy". The most obvious point is that the site of a shrine is often a matter of interest to an area, not just an individual settlement. It causes traffic, and can influence the direction of spread, or even the location of a settlement. Again, sectarian differences (a

${ }^{3}$ During the last decade one of the villages (Jūymand) has in fact been made into a regional centre for administrative purposes and given the name Gunābād, which previously did not apply to any one settlement. This has naturally affected the pattern of relationships between the villages. 
special feature in the case of Kirmān) tend to cause spatial segregation in the population, and are therefore also likely to leave a mark on settlement. (This is noted for the city but not the villages.)

5. In a sense, the " diachronic study" is another and a necessary aspect of the " regional study" and there is much to be said for the inclusion of a chapter on the " historical development of settlement" in roughly the position in which we find it. However, in this particular case it does not appear to support either the general argument or the conclusions of the book. In addition to this, much of the historical synopsis given is either based on obscure authorities, or is simply one possible interpretation of rather scanty data. But the most significant part of the chapter is the account of the foundation of the city of Kirmān and the colonization of the Basin, which is shown to account for an unusual lack of communalism. Kirmān was founded by the first Sasanian king " as a defensive outpost of the ... Empire. ... The site ... was chosen for defensive reasons. ... The present functionally integrated settlement pattern was initiated by this well-equipped feudal society which, as it grew, extended its capital, labor, and technology outward to the alluvial fans and later into the mountains ....".

" This settlement process explains the paucity of communal traits in the villages of Kirmān as compared with other areas of Iran" (pp. 2I-3). This ideal is developed later on. For instance: " every qanät in the Kirmān Basin (for which records exist) was built by a member of the urban élite, whether merchant or landlord" (p. 66). This does not help to prove that Kirmān is typical. ${ }^{4}$

6. Another factor which could be used to much better advantage in this study is the role of communications. We are told that Kirmān was not on a major trade route in early Abbasid times (p. 25; the account of the trade routes existing at that time which he provides in the next sentence is very confused), and that " from the European vantage point, the raison d'être of cities such as Mashhad, Tehran, Tabrìz, Ișfahān, and Kirmān has historically been international trade " and that this is wrong (pp. I I I-12). But we are not told of the effects on local prosperity when one arterial route is for some external reason superseded by another. We are even told that the coming of the motor age merely " intensified and expanded an existing pattern" (p. 66), whereas there certainly are cases where patterns of communications have been completely changed by the advent of motor traffic (cf. e.g. Spooner, I 965$)$. Perhaps this was not the case in the Kirmān Basin, but English claims general validity for his statements, and the extreme case of Shahdād (just east of Kirmān) is close at hand: by donkey it used to be sixty miles from the city; by motorized transport it is now 280 miles. ${ }^{5}$ Communications, trade, prosperity - these are always surely complementary parameters.

7. Though we have already shown that English's argument from natural conditions does not help his case, nevertheless it still calls for some comment on detail. Firstly, that any use of Persian statistics should be accompanied by a caution-even if only because we know that in the case of rainfall there is not a long enough run to give a valid mean. Secondly, the most important form of precipitation for the Kirmān Basin is surely not rain in the Basin at all, but the snow which falls in winter on the surrounding high mountains. For it is this which replenishes the aquifers from which the qanats draw the water for irrigation. No mention is made of this. Rain in the Basin itself of course also plays its part, but it is not so much its quantity and distribution as its intensity and its irregularity which are important. An inch of rain or more may fall in less than twenty-four hours, but in doing so it may generate such force of run-off that damage to qanāts and other capital property will far outweigh any addition to the water table.

8. The fact that the centre of the Kirmān Basin is practically a sand sea may perhaps also be seen as a factor affecting the unity of the region. Such a feature may often be a factor in making the centres of plains or depressions into borders of regions, and causing settlements built on alluvial fans to form their relationships with their neighbours on the other side of the range (assuming there are convenient dry river beds and passes) rather than with the villages they can see across the plain. However, in this case the magnetic pull of an urban centre the size of Kirmān would counteract any such tendency.

4 It is worth noting that in a footnote to this passage English admits that he is rejecting the opinion of the most generally accepted authority on this particular subject.

${ }^{5}$ It is nevertheless a little quicker by jeep than by donkey. However, Shahdād now exports its citrus fruit harvest to
Birjand which by truck is about the same distance as Kirmān. Thus, the Kirmān market for citrus fruit is supplied by Bam, and Shahdäd supplies the north-east of Iran via Bïrjand. Without motor transport the two producing areas would be forced to compete for the Kirmān market. 
9. English's whole reason for weighting the interpretation of his material in this way is that he considers that " it is customary for writers to divide Middle Eastern society into three sectors-city, village and tribe-each rooted in a separate social environment, each exploiting a different physical environment" (p. xvii). I contend that the prevalence of this "tripartite" view is greatly overemphasized. English justifies it by four long bibliographical footnotes. I may be wrong, but I do not think any of the works cited actually states this " tripartite" view in so many words. Most of them (in notes 2, 3 and 4) are simply " unit studies", rather than " regional studies". And English himself says that he does not mean to "imply that a geographical approach precludes the study of a single community" (p. I56, note Io). Nevertheless, in several places (cf. e.g. pp. $65,67,87,88$ ) it is somewhat vaguely suggested that a whole " literature" exists to support this trichotomy. One of the authorities cited (p. I56, note 4) as a non-regional village study (Stirling, 1965) is in fact used again later (p. I70, note $\mathrm{I}$ ) in support of the contention that "the peasantry is an integral, functioning part of a larger society, not a divorced element" (p. 88).

Io. The term feudal is used a great deal, but we are left to guess in what sense it is being used. It is certainly not the sense which may be abstracted from medieval European feudal society because it is used to imply something complementary to centralized urban domination. It seems to be equivalent to Sjoberg's ( I960) usage of the term, and perhaps we were meant to guess this from footnote 13 on p. 157. However, a deviant usage of such an emotive and often misused term should be made much more explicit.

I I. Finally, English would like his material, as he interprets it, to solve the problems not just of Iran but of the whole of the Middle East (cf. pp. xx and I I I-I4). What is the basis of such all-inclusive generalizations? The Middle East is a political concept designed by the West to cover an area which subscribes to one formal religion and has for brief periods during a long history been mostly subject to one political authority. English is by no means the first to attempt to make such broad generalizations, and there is of course at least one sense in which the whole of the Middle East (even from the Atlantic to the borders of China) constitutes one cultural area. But is this really a justification for asking questions like "What is the nature of settlement in the Middle East?" "What is the nature of Middle Eastern social and economic organization?" (p. xx), and attempting to find comparatively simple answers for them (pp. xx and I I I-I4)? The questions are, of course, of great interest, but require a much greater fund of more varied field data before they can be convincingly answered-if they turn out to be, in fact, real questions. ${ }^{6}$

BRIAN SPOONER

\section{BIBLIOGRAPHY}

Barth, F., Nomads of South Persia (Oslo 1961).

Census, 1956: National and Province Statistics of the First Census of Iran: November 1956 (Teheran, August 1961), 2 vols.

Coon, G. S., Caravan: The Story of the Middle East (1964, rev. edn.).

Cooper, M. C., Grass (New York 1925).

Doughty, C. M., Arabia Deserta (London 1933).

English, Paul Ward, City and Village in Iran: Settlement and Economy in the Kirman Basin (Madison 1966).

Gray, Robert F., The Sonjo of Tanganyika (O.U.P. 1963).

${ }^{6}$ I have noticed the following factual errors which the author may like to correct in future editions:

(i) Vazīī, Ahmad 'Alī Khān: Tārīkh-i Kirmän (Sälārìyeh) [History of Kirman] was edited by Muhammad Ibrāhim Bāstanì Pārīiei. (Hāfiz Farmānfarmāiān is the general editor of the series in which it was published, cf. p. 190.)

(ii) The city of Kirmān never served an Iranian province of Baluchistan, though the area known as Baluchistan was always administratively dependent on it. In the past Kirmān and Baluchistan were not separate provinces. At present, both areas are not included within the same administrative subdivision.
Meteorological Yearbook 1957, Iran Meteorological Department (Teheran 1960).

Musil, Alois, The Manners and Customs of the Rwala Bedouins (New York 1928 ).

Sjoberg, G., The Preindustrial City: Past and Present (1960).

Spooner, B. "Arghiyān: the Area of Jājarm in Western Khurāsān ", Iran III (1965).

Stirling, Paul, Turkish Village (London 1965).

Tābandeh, S. H., Nābigheh-i 'Ilm va 'Irfän dar qarn-i chahārdahum (1954) (Tehran I 333 A.H.s.).

They were separated under the Pahlavi regime, and the new city of Zāhidān became first an independent farmāndārīi $i$ kull, and later (1958) a full province (ustān, cf. pp. 5 and 157-8, note 5).

(iii) The world mazra'eh is singular and means "field" (literally: "place of cultivation"). The word does not include the idea of residence, and a mazra'eh is often not residential (pp. 16 and 68).

(iv) Kirmān is east of Sïjān (p. 25).

Lastly, is not the English for Fârsi " Persian " (cf. p. xviii), as, for example, deutsch is German? 